\title{
Forum
}

\section{By the Numbers}

A sense of numbers is essential to understanding political issues, as William I. Buscemi argues persuasively in the December 1997 issue of $P S$. He is to be commended for emphasizing that numbers are not a substitute for reliance on intuition or the "feel" that an artist-political scientist has for reality. Numbers should, of course, be used to help set the terms of political discourse, and point to interesting questions for students and researchers. But which numbers and for what purpose?

Students of comparative politics have long learned to treat numbers with respect and caution. There are no politically innocent statistics. Take the ranking by per capita income of the world's richest nations offered by Professor Buscemi (1997, 740). They are:

$\begin{array}{lr}\text { Switzerland } & \$ 38,000 \\ \text { Japan } & 37,000 \\ \text { Denmark } & 27,000 \\ \text { U.S. } & 26,000 \\ \text { Germany } & 25,000\end{array}$

There is much food for thought here. American students can be challenged to explain why the standard of living in the U.S. is only twothirds that of either Switzerland or Japan. Writing in the early 1980 s, Karl Deutsch poked fun at the presumed American belief that a welfare state interferes with economic growth. "But Sweden has the most elaborate welfare state in the world," he remarked, "and also a higher per capita income than even the United States," citing no source for this selfevident truth $(1995,34)$. Curiously, Sweden does not figure on Professor Buscemi's list of the wealthiest nations; perhaps some calamity has befallen that bastion of social democracy. If we try to understand Deutsch's comment through the numbers offered by Professor Buscemi, the mystery deepens. Why should the U.S. be richer than Germany, with its comprehensive wel- fare system, and richer also than the U.K and France (which do not even make this list)?

Before taking up class time on this nonproblem, perhaps one of the bright students will check the source of Buscemi's figures, a table on page 835 of the Statistical Abstract of the United States (1996). These figures are based on currency exchange values, provided mainly by the International Bank for Reconstruction and Development. Currency values fluctuate wildly, and are notoriously unreliable guides to reality. In terms of purchasing power, the dollar is undervalued, while the yen and most European currencies are overvalued. My artistic-political science "intuition" tells me, for example, that the standard of living in France has not declined by some $20 \%$ in the past year, even though the franc is now worth that much less than the dollar. Experience also is my guide. The francs I earned as a visiting professor in France in November 1996 had about the same purchasing power locally when I spent them the following summer, though down $20 \%$ against the dollar.

Dissatisfaction with international comparisons based on currency values has led economists, notably at the Organization for Economic Cooperation and Development in Paris, to create "purchasing power parities." PPPs show how many units of currency are needed in one country to buy the same amount of goods and services which one unit of currency will buy in other countries. No measure is perfect, but let us assume that economists at the OECD have worked out most of the wrinkles.

Students do not have to go far to find international comparisons based on PPPs. Only one page after the table cited above, the 1996 Statistical Abstract of the United States contains a different and more realistic ranking based on PPPs. More up-to-date and accessible PPP figures may be found in the 1998 World Almanac. Based on PPPs, the five nations pre- viously cited are ranked as shown below.

\begin{tabular}{|c|c|c|}
\hline & $1994^{a}$ & $\operatorname{mid}-1997^{\mathrm{b}}$ \\
\hline U.S. & $\$ 26,000$ & $\$ 28,000$ \\
\hline Switzerland & 24,000 & 22,000 \\
\hline Japan & 21,000 & 21,000 \\
\hline Denmark & 21,000 & 22,000 \\
\hline Germany & 20,000 & 18,000 \\
\hline
\end{tabular}

Source: aU.S. Department of Commerce (1996, 836).

bWorld Almanac (832, 823, 787, 759, 767).

The United States is clearly the richest of these nations. U.S. residents are over $20 \%$ richer (in per capita income) than residents of Switzerland, and between 30 and $50 \%$ richer than residents of the other three nations. Why this should be the case indeed would make for an interesting class discussion. The figures given by Professor Buscemi for the poorest nations are also misleading. The per capita income for India in mid-1997, based on PPPs, is $\$ 1500$ (not $\$ 312$ ); for Ethiopia, $\$ 480$ (not \$91); and for Tanzania, $\$ 800$ (not \$74). It is also worth noting that people are better off in subsistence economies than would appear from even these figures; their needs are different, there is more barter exchange of services and goods, and much economic activity goes unreported. Class discussion based on currency exchange values for both rich and poor nations is largely a waste of time.

Similarly, the notion that money spent on defense could simply be transferred to the world's poor assumes that wealth exists separately from the processes that create it, and can be redistributed by an intellectual exercise. Here is an interesting talking point: What percentage of the money to be cut from military budgets and distributed to the world's poor would wind up in numbered bank accounts in Switzerland? By addressing such a question students may be led to understand why 
Switzerland ranks second among wealthy nations in per capita income, why many poor nations remain poor, and why some poor nations have greater success in modernizing. Foreign aid as a percentage of GDP? Direct aid tends to buy support from local elites (see above comment on numbered bank accounts). The most effective aid is capital investment, particularly in mutual funds that specialize in emerging economies. What is the percentage of government employees to the total workforce? A question that needs to be considered first is under what conditions a bureaucracy helps create wealth, and at what point it becomes a brake on investment and economic activity or even (as Max Weber feared) a threat to human individuality. Why do American workers spend more hours on the job than workers in any industrialized nation "except Japan" (a rather large exception)? Says Professor Buscemi, "perhaps not coincidentally, the percentage of union membership in America is only $16 \%$ compared to Sweden's $85 \%$." But in France union membership is below $10 \%$. Many other factors must be involved.

Figures don't lie. But political scientists and politicians, economists and lobbyists, philosophers and ideologues all can figure.

Bernard E. Brown,

City University of New York

\section{References}

Buscemi, William I. 1997. "Numbers? Borrinnngg!!!" PS: Political Science and Politics 30 (4): 737-42.

Deutsch, Karl. 1995. "The Systems Theory Approach as a Basis for Comparative Analysis." In Comparative Politics: Notes and Readings, 8th ed., ed. B.E. Brown and R.C. Macridis. New York: Harcourt Brace.

U. S. Department of Commerce. 1996. Statistical Abstract of the United States.

The World Almanac and Book of Facts. 1998. New York: Newspaper Enterprise Association.

\section{Call for Political Science Faculty Who Have Received Campus-Wide Teaching Awards in 1997-98}

The APSA will again honor political science faulty whose institutions have recognized their outstanding teaching. Faculty who have received campuswide teaching awards will be invited to the Annual APSA Honors Reception at 6:00 p.m. on Wednesday, September 2, 1998 in Boston, where they will be congratulated on their achievements. The reception precedes the APSA Annual Meeting. The location has yet to be determined.

The Association began recognizing campus-wide teaching award winners at the 1993 Annual Meeting. Beginning this year, Pi Sigma Alpha, the national political science honor society, will cosponsor these awards. Each year, the names and affiliations of the honored faculty are featured in the Annual Meeting Program, and a tribute, which includes award winners' photographs, is published in the December issue of PS. Beginning this year, each winner will also receive a certificate of recognition.

Please help APSA and Pi Sigma Alpha honor outstanding political science teachers. If someone in your department has received a campus-wide teaching award for the 1997-98 school year, please ask your department chair to complete and return the form below as soon as possible, but no later than JULY 20, 1998. An online form can also be found on the APSA web site at www.apsanet.org.

Name of Award winner (please print)

Department

College/University

City, State, Zip Code

Email Phone

Name of Individual Submitting Information

Title of Award \& Short Description 


\section{CONTACTING APSA BY E-MAIL}

apsa@apsanet.org

membership@apsanet.org

bunche@apsanet.org

meeting@apsanet.org

PS@apsanet.org

publications@apsanet.org

minority_id@apsanet.org

PSN@apsanet.org

advertising@apsanet.org

apsr@ssc.msu.edu

information@apsanet.org

The APSA Political Scientists on E-Mail:

rudder@apsanet.org rhavck@apsanet.org smann@apsanet.org woodard@apsanet.org ivin@apsanet.org
Use this address for general inquiries about APSA services not mentioned below.

Send mail to this address to receive information about membership rates and services; request an address change or renew your membership (if you wish to transmit your credit card number by e-mail) or find out about joint memberships with ASA, ASIL, and AHA.

Receive information and applications for the Ralph Bunche Summer Institute, a one month program intended for African-American students between their junior and senior years of undergraduate study.

Find out the latest information on the APSA annual meeting, including registration costs, hotel accommodations, and future sites and dates.

Use this address to submit material for the People in Political Science section and for other "News and Notes" sections; Questions about deadlines and manuscript submissions.

Receive a list of APSA publications, find out the status of an order, and place orders (if you wish to transmit your credit card number by e-mail).

Use this address to submit names of students who are candidates for the Minority Indentification Project and to request additional information about the program.

Send employment listings to the Personnel Service Newsletter, a monthly publication listing employment opportunities for political scientists.

Insertion rates for advertising in PS, APSR, and the Annual Meeting Final Program.

Use this address to contact the editorial office of the American Political Science Review. Please note that instructions for submission of articles to the Review are printed in each issue. The editorial office does not handle business issues. For address changes, advertising, or other non-editorial issues, please contact APSA headquarters at the e-mail addresses listed

For general information about APSA services this automated server will return specific files you request. There are files on membership, publications, research grants, fellowships, and more. Type "send list" in the subject field of your message to receive a list of available files.

Catherine E. Rudder, Executive Director

Robert J-P. Hauck, Deputy Director

Sheilah Mann, Director of Educational Affairs

Maurice Woodard, Director of Minority Affairs

Jun Yin, Program Director 


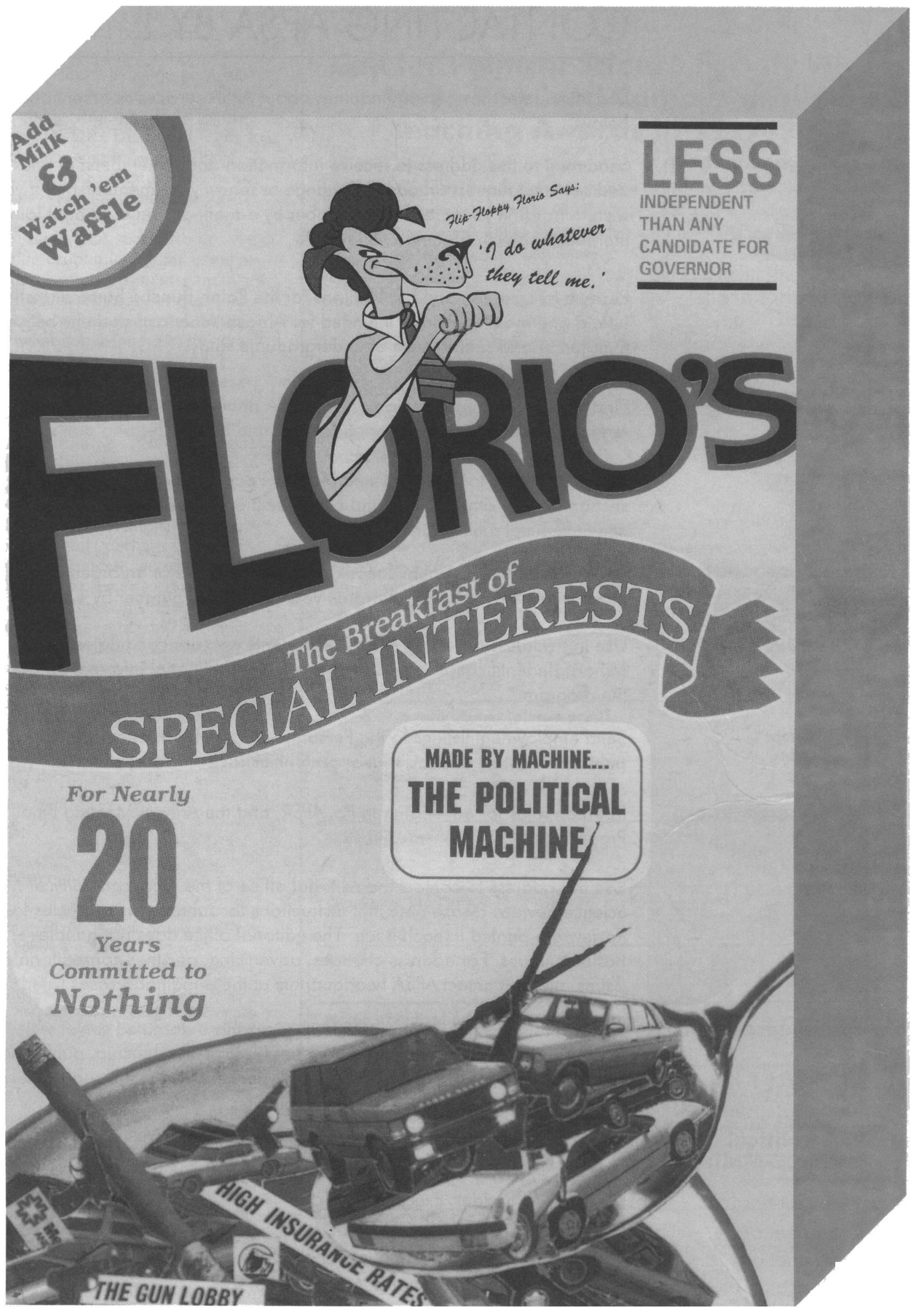

